Farewell to

unreason

\author{
Paul R. Gross
}

The Trouble With Science. By Robin Dunbar. Faber: 1995. Pp. 213. £14.99, $\$ 22.95$.

RoBIN Dunbar, a psychologist and anthropologist at the University of Liverpool, England, bids us to remember not only that science is one among many products of the cognitive tool-set called 'reason', but also that "the human mind was not designed as a rational scientific mind". He provides evidence - the hammer among reason's tools - for both claims in this readable book. Not that the mind's unreason is despised: more often than not over the millennia it has actually been preferred. It has been advanced repeatedly, for instance, by literary scholars and social theorists, from Erasmus in the sixteenth century to modern (and postmodern) voices as various as those of Karl Marx, D. H. Lawrence, Adolf Hitler, Michel Foucault and, most recently, Václav Havel. Lawrence's "belief in the blood, the flesh, as being wiser than the intellect" has the same ancient source as Hitler's maundering to Hermann Rauschning that "Es gibt keine Wahrheit!".

Dunbar's "trouble with science" turns out to be one of several. He does not suggest, however, that science is anything other than the best device for getting at reality. On the contrary: he considers that the trouble-makers are detractors of science who seek to dominate opinion about science or nature, to control science policy or to deny altogether the possibility of truth. But this is no surprise: rationality, especially scientific rationality, has only recently provided any selective advantage over other modes of thinking. Evolution designed primate thought primarily for effective socialization, not for its ability to understand reality.

It has always been stylish to deny that empirical science has any particular distinction as a way of gaining knowledge about the world. And there are now certain benefits in rejecting the very possibility of distinguishing different kinds of knowledge (except, perhaps, for oneself). Irrationalism - including the trendy varieties espoused by post-positivists, some historians of science, the newer sociologists of knowledge and the prides of academic lions and lionesses doing well on identity politics - lies behind this rejection. Unfortunately, the denial is not immured in academic institutions: it titillates a public whose admiration for science when it seems useful or entertaining turns easily to dismissal or hatred when it is difficult or when myths are challenged.

Dunbar worries about the decline of science education in the United Kingdom, where avoidance of science by the brightest students has reached scandalous proportions. In the United States, the situation is equally serious. Of course, some of the brightest students do study science; it is, for example, a requirement for admission to medical schools. But the scientific literacy of the rest - the majority - of students is of no real concern to the university. Worse still, they are taught by staff in other disciplines who are increasingly hostile to science. The scientific artlessness of graduates does harm: it has nothing to do with the funding of the Superconducting Super Collider or with the management of technology; it has everything to do with judging arguments - all arguments - and making informed decisions, whether about teaching and learning, patently false claims (such as 'alternative healing') or environmental threats, real and imagined.

Dunbar has written a strong but accessible defence of science. He has avoided technical detail and the safe selfindulgence of endnotes. (There is however an adequate and carefully selected bibliography.) Yet his points of evidence are not mere assertions; they support the merit of science as a way of finding out about the world and reveal the triviality of its fashionable dismissals. There is, in fact, a modern science - one that pre-dates the Enlightenment science invented by eighteenthcentury Englishmen. The roots of this universal achievement are narrow but lie deep in human evolution. Science works by trying to find explanations, and it has always eventually succeeded - as its

record shows. Strong inference (as John Platt named it) is relatively new, whereas scientific inference, Dunbar argues, in general is not. Nor is it European, or white, or male or hegemonic. It is probably not limited to Homo sapiens. Negotiation creates the consensus (always temporary) of science on any question. But contrary to the belief of the socio-anthropologists of laboratory life, this negotiation is not about bandits apportioning booty. Rather, it is about what kind of evidence allows a definitive rejection or the temporary acceptance of explanations about nature.

Survival of our species, perhaps of all species, depends on our doing the best possible science and on the public's understanding of it. We seem unfortunately to be embarked on a reduction in that understanding. Dunbar's book, among others recently published or being written, is, I hope, a signal of a reaction to the systemic anti-science that has taken root, not only among the Old Right but also among the New Left. It deserves to be widely read not least by journalists and the new academic critics of science - and to be made even more accessible by appearing in paperback as soon as possible (without the amusing misspellings). As regards science as a "way of knowing", Wittgenstein seems for once to have been clear as well as right: about that of which one cannot speak, one should shut up.

Paul R. Gross is at the Centre for Advanced Studies, University of Virginia, 444 Cabell Hall, Charlottesville, Virginia 22903 , USA.

\title{
The New York Review version
}

Walter Gratzer

Hidden Histories of Science. Edited by Robert B. Silvers. New York Review of Books: 1995. Pp. 192. \$19.95.

If you want to have it from the horse's mouth, attend to the words of Clerk Maxwell: one used, he said, to teach the corpuscular theory of light. Now one taught the wave theory; and that was because those who believed in the corpuscular theory had died. Scientists cleave to the common currency of their discipline as to a favourite pair of socks, discarded only with reluctance when they no longer keep out the draught: this is an inalienable feature of the scientific process. Nor can the pursuit of science be separated from tenacious, even passionate, commitment to ideas. From time to time historians of science discover anew that a certain intolerance to gross heterodoxy ensues and that it sometimes impedes the advance of knowledge. But does it not far more often repel folly and keep credulity at bay?
The relationship between entrenched orthodoxy and apostasy forms the broad theme of a collection of essays solicited from his stable of science reviewers by the editor of The New York Review of Books. And on scientists as the enemies of science Oliver Sacks generates the strongest, though not always the most informed, opinions. He recycles some of his earlier stories - good ones, to be sure - and draws on the fates of some scientific paranoiacs to point to a moral. Georg Cantor became "floridly psychotic" on account of his persecution by a mandarin of German mathematics, Felix Klein; Boltzmann was driven to suicide by the attacks on his confrères, and so on. But Boltzmann, a depressive certainly, was a full professor at 25 , was summoned for an audience by the Emperor Franz Josef, attracted the adulation of the younger physicists and was generally held to have vanquished his intellectual opponents, such as Ostwald, by the time his confidence failed. The career of Chandrasekhar and the rise of

NATURE · VOL $374 \cdot 27$ APRIL 1995 
relativistic astrophysics were no doubt held back by the opposition of his former patron, Eddington, who nevertheless became the most articulate apologist for Einstein and a leading exponent of the theory of the expanding Universe. Far more remarkable than Sacks's examples of resistance to assaults on the established order is, so it seems to me, the speed with which the revolution in physics in the first decades of this century took hold and the eagerness with which so many of the best physicists seized on the implications of relativity, quantum theory and uncertainty.

I also feel Sacks's thesis that Goethe's theory of colour perception, spurned by his scientific contemporaries, has been vindicated by Edwin Land's "relativity" hypothesis is stretching it a little. Everything, of course, has been prefigured at some time, just as all the prophecies of Nostradamus have been fulfilled. Salvador Dali pointed to a helix in the corner of one of his early canvases as proof that it was he who had discovered the structure of DNA. And was the phlogiston theory really, as Sacks asserts, "preposterous"? For a long time it actually answered very well, and could one not argue that it rather accurately anticipated the classification of exothermic and endothermic reactions? But now Sacks, having softened up the reader with these prods to the ribs, fells him with a kidney-punch: Freud's case histories, he declares, now confidently on home territory, are "serious science, and they embody and point to a science of the individual which is every bit as 'hard' as physics or molecular biology". (Oh, Medawar, thou shouldst be living at this hour!) Were the prevailing orthodoxies in the clinical psychiatry of only a few years ago then, such as frontal lobotomies and electroconvulsive therapy, equally firmly rooted in 'hard' science?

Jonathan Miller also ruminates, though less assertively, on anticipated discoveries - ideas that arrived too early for the existing corpus of knowledge to assimilate. Miller makes the journey from Mesmer and the myth of animal magnetism that caused such a frisson in eighteenth-century Europe, until it was debunked by the famous commission of savants set up by Louis XIV ("L'imagination fait tout, le magnétisme nul"), to the English neurologist John Hughlings Jackson and the function of the cerebral cortex. He takes a tortuous, though interesting, route to his final conclusion - that the mind is aware of only a small part of itself, for it contributes unbidden to much of what we perceive, and that this same message fell on deaf ears for a century and more.
Richard Lewontin's essay is a rebuttal of determinism and an assertion of the influence of the environment on development and form. (Unspoken in the background are the many exasperated words that Lewontin has already expended on the great red herring of genes and intelligence.) If the environment alters the organism, he says, the organism also impinges on its environment. Therefore the desire that man should leave the and cancer", and his heroes are a succession of intrepid researchers - Peyton Rous, John Bittner and Ludwik Gross prominent among them, and in our own time the pioneers of RNA viruses, reverse transcriptase and oncogenes - who breached the prevailing orthodoxy and in time supplanted it, in the face of much scepticism and sometimes hostility. Gross was perhaps the most remarkable in his faith and persistence, for he conducted his experiments on the transfer है of leukaemia between mice in \& the time that he could spare from his work as a hospital doctor over seven long years with no grant, until, not without a slice of luck, he prevailed. As for Bittner, convinced as he was that the agent of breast cancer in his mice was a virus, he found it prudent to refer to it as a "factor", because the cancer virus hypothesis had been discredited, and denounced indeed, in a report by the US Surgeon General. Had Bittner allowed the word to slip out in a publication he would, he believed, have been branded a crank and forfeited all prospects of grant support.

Kevles suggests that, in today's climate, Gross, whose success in transferring the leukaemia virus world in the condition in which he found it is misplaced. Lewontin's views will have little appeal for the environmentalists, for he implicitly discounts the unique powers that man has developed for inflicting such calamitous abuse on his surroundings. Man in our time, Julian Huxley believed, had become the cancer of the Earth; Lewontin will have none of that.

Stephen Jay Gould is on good form in his homily on how imagery or, as he calls it, iconography, subverts thought. The evolutionary tree or the very form of the conventional 'cone' of biological diversity, drawing the eye upwards, has helped to perpetuate the identification of evolution (a term that Darwin felt was inherently misleading) with improvement. This view of evolution as a purposeful process, by which the organism improves its performance, was expounded by such influential popularizers as $\mathrm{C}$. $\mathrm{H}$. Waddington in the 1930 s and 1940s, and is still evidently lodged in the public perception. Gould shows how merely opening out the cone diagram for the life-forms of the Burgess Shale creates a different and, he persuades us, truer impression. Perhaps the common representation derives from the traditional portrayal of human pedigrees (from pied de grue, or a crane's foot, with toes deviating slightly from the vertical).

The most absorbing of the pieces in this collection is (to me) that of Daniel Kevles. He calls his story "Pursuing the unpopular: a history of courage, viruses turned out to be a function of the strain of mice that he happened to be using and was for some time not reproduced by other labora-tories, might have been hauled before the Holy Office (of Research Integrity, that is) and cast into darkness. Of course, such devotion to a belief as Gross's is rare in science, as in other human endeavours. Consider, for instance, Trollope's evaluation of seekers after public office: "If membership of the Treasury bench were confined to men who believe the world to be triangular, then there would arise from Ministerial aspirants a great assertion of triangularity." But Kevles does not draw the facile conclusion vociferated by so many critics of science. Here is his moral: "What permitted the pioneers eventually to prevail was to a significant extent their professional courage, imagination, and persistence. Yet it was also the tolerance and pluralism of the basic biomedical research system - the tolerance of deviant ideas and the pluralism that provides niches (large like Rous's and Temin's or small like Gross's) in which the ideas have a chance to flourish."

Robert Silvers, the editor, has inspired a rewarding collection of good writing. Even where the substance inflames, the literary excellence assuages. Let's hear it for The New York Review of Books.

Walter Gratzer is at the MRC Muscle and Cell Motility Unit, King's College, 26-29 Drury Lane, London WC2B 5RL, UK. 